\title{
Experimental Therapeutic Trial of an Antibody against the Cell Adhesion Molecule Gicerin for Lymphomas Using a Murine Cell Line
}

\author{
Yasuhiro Tsukamoto*, Yukiko Miyagawa, Osamu Maeda \\ Department of Animal Hygiene, Graduate School of Environmental \& Biological Sciences, Kyoto Prefecture University, \\ Kyoto, Japan \\ Email: *ytsuka@kpu.ac.jp
}

How to cite this paper: Tsukamoto, Y., Miyagawa, Y. and Maeda, O. (2018) Experimental Therapeutic Trial of an Antibody against the Cell Adhesion Molecule Gicerin for Lymphomas Using a Murine Cell Line. Journal of Cancer Therapy, 9, 807-819. https://doi.org/10.4236/jct.2018.910066

Received: September 19, 2018

Accepted: October 12, 2018

Published: October 15, 2018

Copyright $(9) 2018$ by authors and Scientific Research Publishing Inc. This work is licensed under the Creative Commons Attribution International License (CC BY 4.0).

http://creativecommons.org/licenses/by/4.0/

\begin{abstract}
Chemotherapy, occasionally combined with radiotherapy, is a major method for treating lymphoma but frequently produces side-effects in patients. Thus, novel therapeutics should be developed as an alternative the chemotherapy in lymphoma patients. Although the cell adhesion molecule gicerins are almost entirely absent in most mature tissues, except for muscle and endothelial cells, various neoplastic cells strongly express gicerin in their cell membranes. This suggests the potential function of gicerin in the progression of tumors, including tumor growth, invasion and metastasis to distant organs from primary sites. In the present study, we assessed therapeutic effects of anti-gicerin antibodies on the murine lymphoma cell line YAC1. Gicerin was found to be expressed in the cell membrane of YAC1 cells and promoted the cell adhesion activity of the YAC1 cells on HUVECs, an endothelial cell line. In addition, YAC1 cells were implanted sub-cutaneously in mice in order to examine the therapeutic effects of anti-gicerin antibodies on lymphoma progression in vi$v o$. The anti-gicerin antibodies suppressed and reduced the lymphoma tumor growth in the mice, whereas the growth of tumor mass was not inhibited by pre-immune IgG administrations. YAC1 cells were also implanted intravenously in mice in order to examine the effects of anti-gicerin antibodies on the pulmonary metastasis of lymphoma cells. The metastasis of the YAC1 cells to the lungs was inhibited by the injection of anti-gicerin antibodies. These findings indicate that anti-gicerin antibodies inhibit the progression of prednisolone-resistant lymphoma, making this a promising novel therapeutic method for treating refractory lymphoma cases.
\end{abstract}

\section{Keywords}

Gicerin, Cell Adhesion Molecule, Lymphoma, Mouse 


\section{Introduction}

Lymphoma is a tumor originating from the lymphocytes. As there are numerous lymphatic tissues in the body and various kinds of lymphocytes circulating in the bone marrow, blood and lymphvessels, lymphoma can be found in all organs [1] [2]. At present, the major therapeutic treatment of lymphoma is anti-cancer drugs and X-ray therapy. The CHOP regimen, characterized by several cycles of cyclophosphamide, hydroxydaunorubicin, oncovin and prednisolone, is the most common and effective chemotherapeutic method for treating B cell lymphoma [3]. However, these anticancer drugs have strong side-effects and reduce the quality of life of lymphoma patients [4] [5]. A number of studies have attempted to develop novel therapeutics for malignant lymphomas [6] [7]. Treatments targeting membrane proteins of lymphoma cells have also been developed and clinically applied to patients. Approaches using not only anticancer drugs but also antibodies are particularly promising and have received increasing attention.

To develop a potential molecular-targeted therapy for lymphoma, we focused on cell adhesion molecule gicerin, which is expressed on the cell membranes of avian lymphoma cells, in the present study [8]. Gicerin is an immunoglobulin-superfamily cell adhesion molecule purified from chicken smooth muscle as a neurite promotion factor [9] [10]. Gicerin contains five Ig-like domain structures in its extracellular region: each domain is rendered stable by a disulfide cross-link between two beta-plated sheets. Gicerinalso has two isoforms: L-gicerin and S-gicerin, which have intracellular tailsof different sizes [11]. In our previous studies, L-gicerin was observed in invasive and metastasizing cancer cells and enhanced the invasive and metastatic activities of neoplastic cells in vivo [12] [13].

Gicerin proteins have homophilic cell adhesion activities with respect to cell-cell interactions. It can be found in embryonic tissues, including the nervous system, kidneys and respiratory system, and plays a role in cell migration, neurite extension, epithelialization and cell condensation via its cell adhesive activity [12]-[21]. Gicerin is almost entirely absent in mature tissues, being restricted to muscles and endothelial cells in blood vessels. However, gicerin has been found to be over expressed in various sporadic tumors in animals [11] [14]-[19] [22] [23] [24]. It has also been demonstrated that lymphoma cells strongly express gicerin in their membrane. Given these previous findings, we considered that targeting gicerin might be a new approach to treating lymphoma.

In the present study, we attempted to treat lymphoma via injections with anti-gicerin antibody in in vivo animal models bearing an implantable murine lymphoma cell line.

\section{Materials and Methods}

\subsection{Cell Culture}

The mouse lymphoma cell line YAC1 and human umbilical vein endothelial 
cells (HUVECs) were used in this experiment. YAC1 cells and HUVECs were cultured in DMEM (Nakarai Tesque) containing $10 \% \mathrm{FBS}$ at $37^{\circ} \mathrm{C}$ in $5 \% \mathrm{CO}_{2}$.

\subsection{Expression of Gicerin in YAC1 Cells}

For RNA extraction, YAC1 cells were cultured on a dish. Since YAC1 cells were grown under unattached conditions (floating cells), $10 \mathrm{ml}$ of cell culture was centrifuged at $800 \mathrm{rcf}$ for 10 minutes. The pellets were solubilized using $1 \mathrm{ml}$ Trizol and mixed $200 \mu \mathrm{l}$ chloroform. After being left to stand for 10 minutes, the solution was centrifuged as $15,000 \mathrm{rpm}$ for 15 minutes at $4^{\circ} \mathrm{C}$. The supernatant was then mixed $500 \mu$ isopropanol and left to stand for 30 minutes in a freezer, after which the solution was centrifuged at $15,000 \mathrm{rpm}$ for 15 minutes at $4^{\circ} \mathrm{C}$. The pellets were mixed with $1 \mathrm{ml} \mathrm{75 \%}$ ethanol and centrifuged at 15,000 rpm for 15 minutes. After air drying, the pellets were solubilized using $40 \mu \mathrm{l}$ DEPC-treated water. cDNA was synthesized from this RNA using a ReverTra Ace (TOWA). Polymerase chain reaction (PCR) was performed using PCR Master Mix (Promega) and carried out in a thermal cycler programmed with the following conditions: $95^{\circ} \mathrm{C} 8$ minutes, $94^{\circ} \mathrm{C} 30$ seconds, $50^{\circ} \mathrm{C} 30$ seconds and $72^{\circ} \mathrm{C} 40$ seconds: 35 cycles, followed by $72^{\circ} \mathrm{C} 10$ minutes. The primers for the sequencing of gicerin genes were as follows: forward

5'-GTCCCCGTGGATGGCAGCAAGG-3' and reverse

5'-TAATGCCTCAGATCGATGTATTTCTC-3'. The PCR product was electrophoresed with $1 \%$ agarose gel, and the gicerin genes were detected by the DNA band of the electrophoresed gel.

For immunohistochemistry, YAC1 cells were cultured in DMEM. YAC1 culture $(1 \mathrm{ml})$ was centrifuged at $400 \mathrm{rcf}$ for 3 minutes. The pellets were mixed with $500 \mu \mathrm{l}$ Zamboni's solution. The cells were then centrifuged at $400 \mathrm{rcf}$ for 90 seconds, and Zamboni's solution was cleanly removed. After being washed in PBS, the YAC1 cells were incubated with a rabbit polyclonal antibody against gicerin protein (1:500) at $37^{\circ} \mathrm{C}$ for $1 \mathrm{~h}$ [18]. Following washing in PBS, the cells were reacted with an FITC-conjugated swine antibody against rabbit Ig (1:200) (DAKO) at $37^{\circ} \mathrm{C}$ for $1 \mathrm{~h}$. Finally, the cells were placed onto a slide glass, and specific signals in the gicerin protein were examined under a florescent microscope with a B-filter (Nikon).

\subsection{Subcutaneous Implantation of YAC1 Cells to Mice}

YAC1 cells were cultured and then suspended at $2.25 \times 10^{7}$ cells $/ \mathrm{ml}$ in DMEM. The cells in $0.1 \mathrm{ml}$ DMEM were injected subcutaneously into the cervical back of female nude mice at 9 weeks of age. After 15 days, 3 mice were orally administered $0.2 \mathrm{ml}$ PBS or $2.5 \mathrm{mg}$ prednisolone in $0.2 \mathrm{ml}$ PBS in the morning and evening for 2 days. The tumor volume was recorded every day, and the mass volume was calculated using the following formula: $A^{2} \times B / 2$, where $A$ is the smallest and B is the largest size.

At 8 days after the injection of YAC1 cells, an anti-gicerin polyclonal antibodyor pre-immune IgG ( $0.1 \mathrm{mg} / \mathrm{animal})$ was directly injected into the tumor mass 
of nude mice ( 5 animals per antibody) on alternate days. The tumor volume was recorded every day. At one week after the injection of antibodies, the mice were sacrificed by injection of pentobarbital solution, and the tumor mass and the lungs were removed and fixed with buffered formalin for histopathology.

\subsection{Histopathology}

The formalin-fixed samples were dehydrated with serial concentrations of ethanol and embedded with xylene and paraffin using a automatic processor: 70\% ethanol for $3 \mathrm{~h}, 80 \%$ ethanol for $3 \mathrm{~h}, 90 \%$ ethanol for $3 \mathrm{~h}, 100 \%$ ethanol for $1 \mathrm{~h}$, $100 \%$ ethanol for $1 \mathrm{~h}$, ambient ethanol-xylene $(1: 1)$ for $1 \mathrm{~h}$, xylene for $2 \mathrm{~h}$, xylene for $2 \mathrm{~h}$, xylene:paraffin-toluene (1:3) for $2 \mathrm{~h}$, paraffin for $2 \mathrm{~h}$, paraffin for $2 \mathrm{~h}$ and paraffin for $3 \mathrm{~h}$. The samples were then embedded in Patho-prep low-melt paraffin. Sections of $3 \mu \mathrm{m}$ in thickness were cut using a microtome and attached to Mass-coated slide-glasses. The sections were dried and de-paraffinized in xylene for 5 minutes $\times 3$ times, $100 \%$ ethanol for 5 minutes, $100 \%$ ethanol for 2 minutes $\times 2$ times, 90\% ethanol for 2 minutes, $80 \%$ ethanol for 2 minutes and $70 \%$ ethanol for 2 minutes. They were then stained with hematoxylin (Wako) for $15 \mathrm{mi}$ nutes and washed with running tap water for 20 minutes. The sections were soaked in distilled water, stained with eosin (SIGMA-Aldorich) for 20 minutes and serial-dehydrated with ethanol and immersed in xylene as follows: $100 \%$ ethanol for 2 minutes $\times 3$ times, $100 \%$ ethanol for 5 minutes, xylene for $2 \mathrm{mi}$ nutes $\times 2$ times and xylene for 10 minutes. Finally, the sections were mounted with cover-glass using Canada balsam and examined under a light microscope.

\subsection{Injection of YAC1 Cells into the Tail Vein of Mice}

YAC1 cells were cultured and then suspended at $7.5 \times 10^{8}$ cells $/ \mathrm{ml}$ in DMEM. The cells in $0.1 \mathrm{ml}$ DMEM were injected into the tail vein of female SCID mice at 9 weeks of age (10 animals). The mice had been pre-injected with anti-gicerin polyclonal antibody or pre-immune $\operatorname{IgG}(0.1 \mathrm{ml} / \mathrm{animal})$ at a subcutaneous site as a single shot ( 5 animals per antibody). At 4 days after the injection of cells, anti-gicerin polyclonal antibody or pre-immune IgG $(0.1 \mathrm{ml} / \mathrm{animal})$ was injected subcutaneously into the mice. Each antibody was then injected twice on alternate days. At one week after cell injection, the mice were sacrificed by injection of pentobarbital solution, and the lungs were removed and fixed with buffered formalin for histopathology.

\subsection{Cell Migration Assay in Chemotaxis Chamber}

The cell locomotion activity was assayed by a convenient in vitro method. The YAC1 cells were pre-incubated with anti-gicerin rabbit polyclonal antibody or pre-immune IgG or DMEM for $1 \mathrm{~h}$ at $37^{\circ} \mathrm{C}$ and suspended at $1.2 \times 10^{7}$ cells $/ \mathrm{ml}$ in DMEM. Each culture solution $(200 \mu \mathrm{l})$ was then incubated in chemotaxis chambers (Kurabo) coated with gicerin protein or BSA (as a negative control) for $12 \mathrm{~h}$ at $37^{\circ} \mathrm{C}$. The cells that migrated through the membrane were counted under an inverted microscope. 


\subsection{In Vitro Cell Adhesion of YAC1 Cells to HUVECs}

HUVECs were cultured on culture dishes and used as feeder layers. YAC1 cells were pre-incubated with anti-gicerin antibodyor pre-immune IgG $(0.1 \mathrm{mg} / \mathrm{mL})$ or DMEM for $1 \mathrm{~h}$ at $37^{\circ} \mathrm{C}$. After being washed in PBS and brieflycentrifuged, the cells were suspended in DMEM $\left(2.5 \times 10^{5}\right.$ cells $\left./ \mathrm{ml}\right)$ and seeded onto the HUVEC monolayers. After $2 \mathrm{~h}$ of incubation at $37^{\circ} \mathrm{C}$, the cultures were gently washed with DMEM, and the YAC1 cells adhering to the feeder layers were observed and counted under an inverted microscope. The cell number per area was determined; the examination was performed in 5 areas, and the average score and standard deviation were calculated.

\section{Results}

\subsection{The Expression of Gicerin in YAC1 Cells}

Doublet DNA bands were found in the electrophoresed gel on PCR using a set of primers corresponding to gicerin genes. A faint lower band was seen at around $600 \mathrm{bp}$, while another stronger band was detected at around $650 \mathrm{bp}$ (Figure $1(\mathrm{a})$ ). The weaker band was identical to the length of the $S$-isoform gicerin gene, while the stronger was the L-isoform. These findings indicated that both isoforms appeared in YAC1 cells in which L-isoform gicerin is predominantly expressed compared to S-isoform gicerin. Immunocytochemically, the expression of gicerin proteins in the YAC1 cells was examined using anti-gicerin polyclonal antibody, with gicerin proteins found to be expressed in a membraneous fashions (Figure 1(b)).

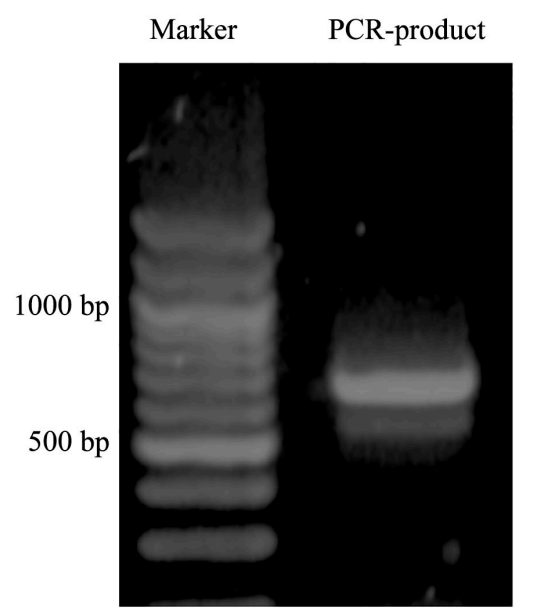

(a)

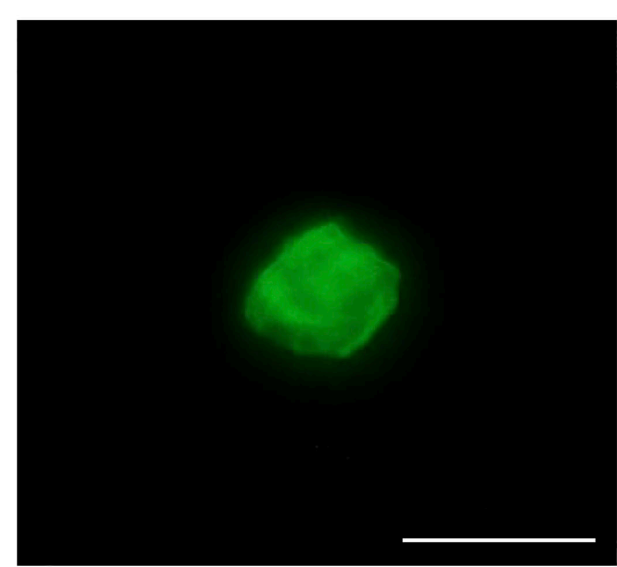

(b)

Figure 1. The expression of gicerin in YAC1 cells. The expression of gicerin mRNA in YAC1 cells was determined by RT-PCR (a), and that of gicerin proteins was determined by immunocytochemistry; (b). RT-PCR showed doublet bands around 650 and $600 \mathrm{bp}$ corresponding to the sizes of the L- and S-gicerin gene, respectively. The expression of the L-isoform was higher. Immunofluorescently, gicerin proteins appeared strongly at the cell surface of a YAC-1 cell aggregate (FITC). The left panel on the PCR gel is the 100-bp ladder marker. Bar, $100 \mu \mathrm{m}$. 


\subsection{The Therapeutic Effect of Anti-Gicerin Antibody on the Tumor Growth Activity of YAC1 Cells in Mice}

The YAC1 tumor mass volume in the back of nude mice was measured every day after injection with anti-gicerin antibody or pre-immune IgG (control) injection. With repeated injections of anti-gicerin antibody, the tumor volume shrank over time (Figure 2). At five days after the initial injection with antibody, the tumor mass was significantly smaller than in mice receiving control IgG injections. A histopathological examination showed atypical lymphatic cell growth and invasion of the surrounding tissues in subdermal areas in mice implanted with YAC1 cells (Figure 3). In contrast, necrotic cells and debris were seen in most areas of tumor by injections of anti-gicerin antibodies. In addition, tumor cells were detected in the lungs of two cell-implanted mice receiving control antibody, showing atypical lymphatic cells with a round to spindle-like shape growing perivascularlyas well as in the pulmonary mesenchyma, suggesting they might be hematogenous pulmonary metastases of YAC1 cells. To determine whether the tumor dwarfing was due solely to the anti-gicerin antibody or could be attributed to an in vivo environmental effect, an in vitro cell proliferation assay of the YAC1 was performed in GIT medium with anti-gicerin antibody or pre-immune IgG. The results showed that the anti-gicerin antibody was not involved in the cell proliferation of YAC1 cells. The cytopathic effects were also not found. So, it seemed that anti-gicerin antibody was not toxic in culture YAC-1 cells (data not shown).

\subsection{Adherent Activity of YAC1 Cells to HUVECs}

YAC1 cells were seeded onto a feeder layer of HUVECs. The numbers of YAC1 cells attaching to the feeder layer were significantly lower under conditions of preincubation with anti-gicerin antibody than with pre-immune (control) IgG (Figure 4). Thus, the antibody was deemed to have inhibited the interaction of YAC1 cells with HUVECs.

\subsection{The Cell Migration Activity of YAC1 Cells}

To confirm the relationship between gicerin proteins and the vascular permeability of YAC1, a cell locomotion assay was performed using convenient chemotaxis chambers coated with gicerin proteins. The YAC1 cells incubated with anti-gicerin antibody merely passed through the membrane pore of the chemotaxis chambers (Figure 5), and the numbers of cells in the lower chamber were significantly lower on exposure to anti-gicerin antibody than preimmune IgG. This finding suggests that gicerin proteins might be involved in the vascular permeability of YAC1 cells.

\subsection{Pulmonary Metastasis of YAC1 Cells in Mice}

Since we failed to establish a repeatable model of pulmonary metastasis of YAC1 in nude mice, SCID mice were used in this trial instead of nude mice. As a result, we succeeded in generating a model of pulmonary metastasis of YAC1 in SCID 
mice. YAC1 cells were injected into the tail vein of mice followed by the daily administration of anti-gicerin antibody. At five days after cell injection, the pulmonary sections were stained and examined histopathologically. The metastasizing foci in pulmonary tissues were counted. The number of YAC1 cells per area was lower in the antibody-injected mice than in the pre-immune IgG animals (Figure 6). These findings suggest that the hematogenous metastasis of $\mathrm{YAC} 1$ in mice was suppressed by anti-gicerin antibody.

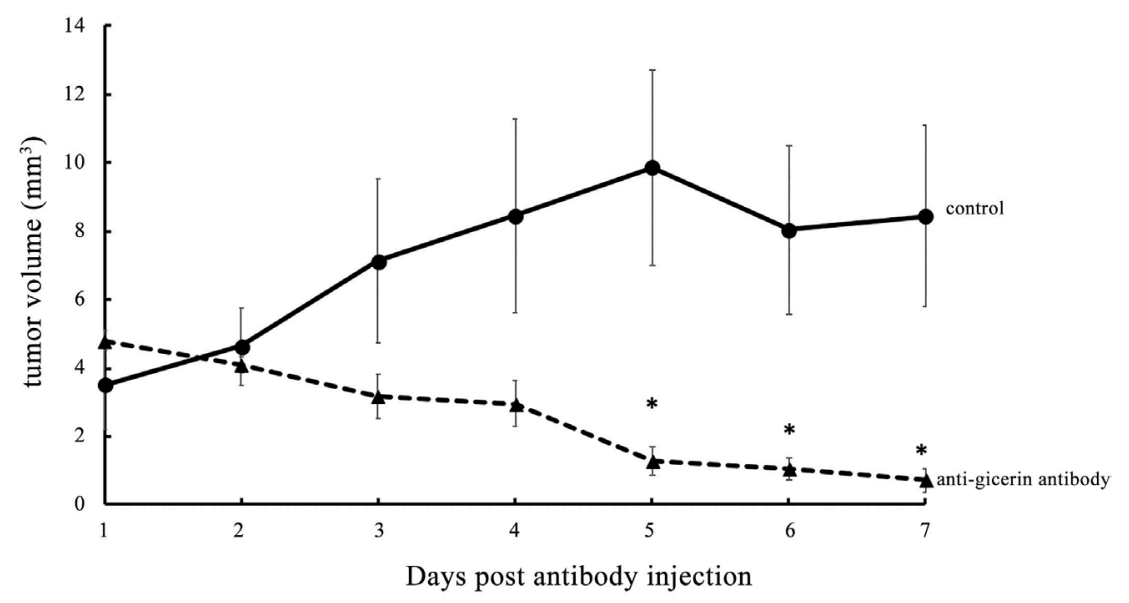

Figure 2. The effect of anti-gicerin antibody on the tumor growth activity of YAC1 cells in nude mice. Through injections of anti-gicerin antibody, the tumor volume on the cervical back of mice began to shrink over time. At five days after the initial injection with anti-gicerin antibody, the tumor mass was significantly smaller than in mice receiving pre-immune IgG (control) injections. ${ }^{\star} P<0.01$ compared with the control (Student's $t$-test).

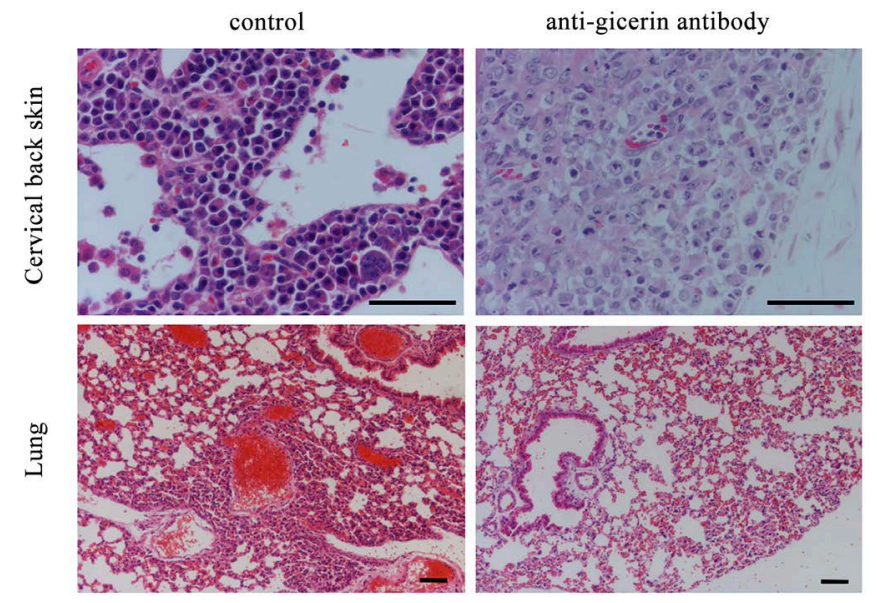

Figure 3. Histopathology of the tumor mass on the cervical back skin of nude mice implanted with YAC1 cells. In the sections from pre-immune IgG (control)-injected mice, atypical lymphatic cell growth and invasion of the surrounding tissues in the subdermal areas were noted in mice implanted with YAC1 cells. In contrast, numerous necrotic cells and debris were seen in most areas of tumor tissues of mice treated with anti-gicerin antibody. Pulmonary metastases of cells were also detected in mice injected with control antibody, whereas no pathologic findings were seen in the lungs of mice treated with anti-gicerin antibody. Bar, $200 \mu \mathrm{m}$. 


\section{Discussion}

In our previous studies, gicerin was revealed to promote the development, regeneration, malformation and tumorigenesis of tumors [9] [25]. Gicerin has homophilic and heterophilic cell adhesion activities, with cell-to-cell binding promoted by gicerin's homophilic adhesion activity and cell-to-ECM adhesion promoted in a heterophilic manner [19] [20]. These functions are involved in the histogenesis of normal and pathologic organs. Malignant cells are involved in proliferation, locomotion and metastasis, the progression of which requires various cell-cell and cell-ECM interactions. The expression of cell adhesion molecules on tumor cells are key factors influencing their malignancy [26]. Gicerin also participates in tumorigenesis via its adhesive activities. Indeed, the malignant

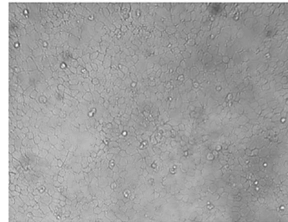

control Adhering YAC1 cells onto HUVEC

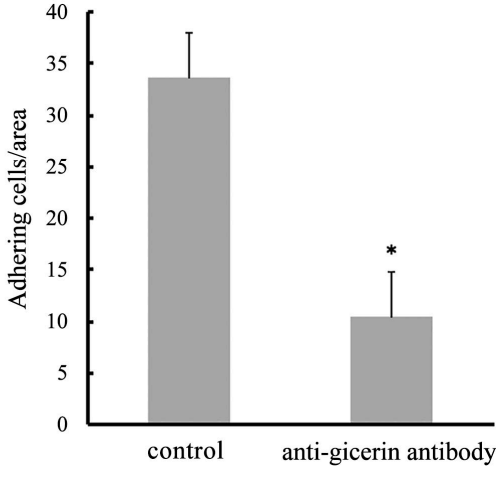

Figure 4. Adherent activity of YAC1 cells to HUVECs. YAC1 cells were seeded onto HUVECs. The numbers of YAC1 cells attaching to HUVEC with pre-immune IgG (control) or anti-gicerin antibodies were counted. The numbers of adhering cells were significantly lower under conditions of preincubation with anti-gicerin antibody than under control conditions. ${ }^{\star} P<0.01$ compared with the control (Student's $t$-test).

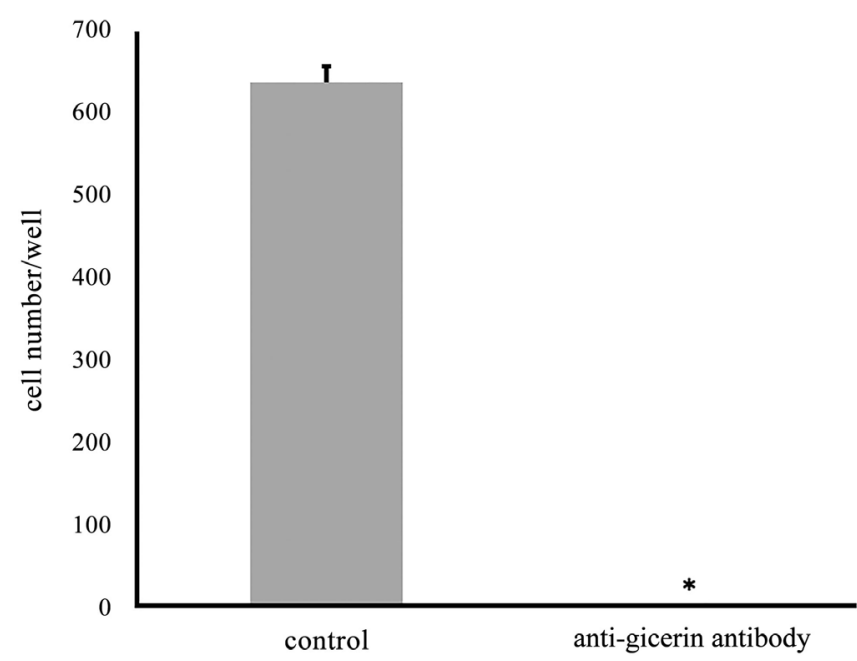

Figure 5. Cell migration activity of YAC1 cells. YAC1 cells were pre-incubated with anti-gicerin antibody or pre-immune IgG (control). The numbers of cells that migrated into the lower chambers were significantly lower under conditions of treatment with anti-gicerin antibody than under control conditions. ${ }^{\star} P<0.01$ compared with the control (Student's $t$-test). 


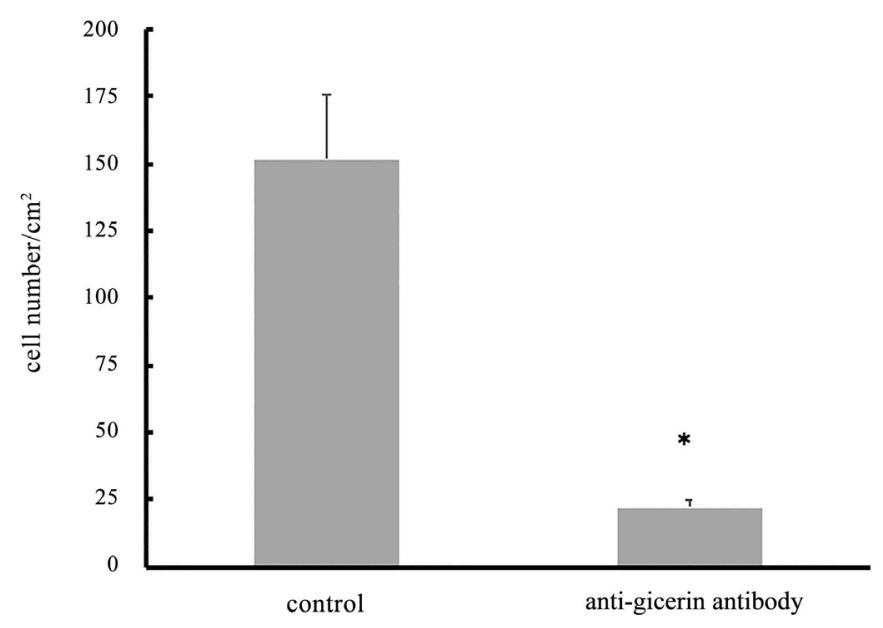

Figure 6. Pulmonary metastasis of YAC1 cells in SCID mice. YAC1 cells were injected into the tail vein of SCID mice followed by daily s.c. administration of anti-gicerin antibody. At five days after the cell injection, the pulmonary sections were stained with hematoxylin and eosin and histopathologically examined, and the number of metastasizing cells in pulmonary tissues was counted. The number of metastasizing YAC1 cells per $\mathrm{cm}^{2}$ was lower in the anti-gicerinantibody-injected mice than in the pre-immune IgG (control) animals. ${ }^{\star} P<0.01$ compared with the control (Student's $t$-test).

progression of oviductalcarcinomas, mammary gland carcinomas, nephroblastomas, Marek's tumor, lung cancer, colorectal adenocarcinomas, melanomas and meningiomas has been reportedly promoted by the expression of gicerin [8] [14] [15] [18] [22] [25] [27]. Regarding the established cell lines, we have found that nephroblastoma cells, melanoma cells expressed gicerin strongly, but fibroblast L-929 cells, colorectal cancer ACL cells, mammary gland carcinoma JYG cells were almost negative for gicerin. Interestingly, the expression level of gicerin was variable in a lung cancer A549 cells by the culture media.

In the present study, the murine implantable lymphoma cell line YAC1 was used to determine the potential role of gicerin in lymphoma progression in vivo. Since YAC1 cells were found to be endogenously positive for gicerin expression, the antibody against gicerin protein was applied to inhibit the function of gicerin in lymphoma cells. Accordingly, YAC1 was deemed to be a suitable cell line for confirming the therapeutic effects of anti-gicerin antibodies on the progression of mammalian lymphoma. The L-isoform of gicerin was predominant in YAC1 cells, indicating the malignant aspects of this cell line, since the L-isoform appears in malignant tumors and strongly promotes the invasion and metastasis of neoplastic cells compared to the S-isoform [13] [23]. The L-isoform promotes F-actin formation by interacting with moesin, a member of the ERM family, resulting in enhanced migratory and metastatic activities of tumor cells [28]. Thus, YAC1 cells seem to beactive with regard to invasion and metastasis based on the isoform expression.

The YAC1 tumor mass volume on the cervical back of mice was clearly shown to be decreased by the anti-gicerin antibody injections. Although pulmonary 
metastases were occasionally detected in the mice implanted with YAC1 cells, no metastasis was found in the lungs of animals injected with anti-gicerin antibody. In situ growth andmetastasis is known to involve a multistep process characterized by a changing relationship between tumor cells and normal tissues, in which the tumor cells must detach from the primary site, intravasate through neighboring cells and/or ECM network and bind to blood vessels and extravasate to sites of metastasis [26] [29] [30] [31]. We suspected that the anti-gicerin antibody might affect the cell-cell and/or cell-ECM interaction in implanted mice, as the in vitro cell proliferation of YAC1 was not affected by the antibody. In addition, complement binding reaction might occur in YAC-1 cells to which anti-gicerin antibody is bound, and cell damage may have occurred. Conversely, since pre-immune IgG did not bind to YAC cells, cells might have no effect. However, additional studies will be needed to confirm this paradigm. Furthermore, in the further studies, we must confirm the half maximal (50\%) effective concentration by injecting a variety of dosage of antibody in mice with respect to anti-tumor effects.

Since both malignant tumors and vascular endothelial cells express gicerin, the interaction between YAC1 cells and endothelial cells was promoted by gicerin, resulting to pulmonary metastasis. A convenient in vitro cell migration assay was therefore performed with gicerin and anti-gicerin antibodies. The results showed that anti-gicerinantibody inhibited the locomotion of YAC1 cells through the gicerin-coated chemotaxis chamber, supporting the hypothesis that lymphoma cells attach to the surface of endothelial cells via homophilic cell adhesive activity of gicerin and invade and spread through the vessel wall.

The most critical and important finding in the present study was that the injection with anti-gicerin antibody suppressed pulmonary metastasis in mice with YAC1 cells injected into the tail vein. The present findings suggest that gicerin is involved in metastasis of lymphoma cells by promoting the tumor-endothelial interactions. Treatment with anti-gicerin antibody might thereforebe effective in patients with lymphoma.

In conclusion, the present study showed that the tumor growth, invasion and metastasis of lymphoma cells in vivo are promoted by gicerin. As anti-gicerin antibody suppresses the cell adhesive activity of gicerin, it will be able to retard the function of lymphoma cells. We attempted to develop a new treatment for lymphoma using anti-gicerin antibody.

\section{Acknowledgements}

The authors thank Mrs. Hatsuki Matsunaga at Kyoto Prefecture University for her technical support.

\section{Conflicts of Interest}

The authors declare that there are no conflicts of interest that could be perceived as prejudicing the impartiality of the research reported. 


\section{References}

[1] Basch, E., Iasonos, A., McDonough, T., Barz, A., Culkin, A., Kris, M.G. and Schrag, D. (2006) Patient versus Clinician Symptom Reporting Using the National Cancer Institute Common Terminology Criteria for Adverse Events. Lancet Oncology, 7, 903-909. https://doi.org/10.1016/S1470-2045(06)70910-X

[2] Brenner, P., Hughes, R.G. and Sutphen, M. (2008) Clinical Reasoning, Decision-Making, and Action: Thinking Critically and Clinically. In: Hughes, R.G., Ed., Patient Safety and Quality. An Evidence-Based Handbook for Nurses, Agency for Healthcare Research and Quality (US), Rockville, 87-109.

[3] Ansell, S.M., Lesokhin, A.M., Borrello, I., Halwani, A., Scott, E.C., Guitierrez, M. and Armand, P. (2013) PD-1 Blockade with Nivolumab in Relapsed or Refractory Hodgkin's Lymphoma. New England Journal of Medicine, 372, 311-319.

https://doi.org/10.1056/NEJMoa1411087

[4] Basch, E., Artz, D., Dulko, D., Scher, K., Sabbatini, P., Hensley, M. and Schrag, D. (2005) Patient Online Self-Reporting of Toxicity Symptoms during Chemotherapy. Journal of Clinical Oncology, 23, 3553-3561.

https://doi.org/10.1200/JCO.2005.04.275

[5] Cirillo, M., Venturini, M., Ciccarelli, L., Coati, F., Bortolami, O. and Verlato, G. (2009) Clinician versus Nurse Symptom Reporting Using the National Cancer Institute-Common Terminology Criteria for Adverse Events during Chemotherapy: Results of a Comparison Based on Patient's Self-Reported Questionnaire. Annals of Oncology, 20, 1929-1935. https://doi.org/10.1093/annonc/mdp287

[6] Basch, E., Jia, X., Heller, G., Barz, A., Sit, L., Fruscione, M. and Schrag, D. (2009) Adverse Symptom Event Reporting by Patients vs Clinicians: Relationships with Clinical Outcomes. Journal of the National Cancer Institute, 101, 1624-1632. https://doi.org/10.1093/jnci/djp386

[7] Brunner, D.W., Hanisch, L.J., Reeve, B.B., Trotti, A.M., Schrag, D., Sit, L. and Basch, E.M. (2011) Stakeholder Perspectives on Implementing the National Cancer Institute's Patient-Reported Outcomes Version of the Common Terminology Criteria for Adverse Events (PRO-CTCAE). Translational Behavioral Medicine, 1, 110-122. https://doi.org/10.1007/s13142-011-0025-3

[8] Tsuchiya, S., Tsukamoto, Y., Furuya, M., Hiroi, S., Miki, N., Sasaki, F. and Taira, E. (2003) Gicerin, a Cell Adhesion Molecule, Promotes the Metastasis of Lymphoma Cells of the Chicken. Cell and Tissue Research, 314, 389-397.

https://doi.org/10.1007/s00441-003-0810-5

[9] Tsukamoto, Y., Taira, E., Miki, N. and Sasaki, F. (2001) The Role of Gicerin, a Novel Cell Adhesion Molecule, in Development, Regeneration and Neoplasia. Histology and Histopathology, 16, 563-571.

[10] Taira, E., Takaha, N., Taniura, H., Kim, C.-H. and Miki, N. (1994) Molecular Cloning and Functional Expression of Gicerin, a Novel Cell Adhesion Molecule That Binds to Neurite Outgrowth Factor. Neuron, 12, 861-872.

https://doi.org/10.1016/0896-6273(94)90338-7

[11] Taira, E., Nagino, T., Taniura, H., Takaha, N., Kim, C.-H., Kuo, C.-H., Li, B.-S., Higuchi, H. and Miki, N. (1995) Expression and Functional Analysis of a Novel Isoform of Gicerin, an Immunoglobulin Superfamily Cell Adhesion Molecule. The Journal of Biological Chemistry, 270, 28681-28687.

https://doi.org/10.1074/jbc.270.48.28681

[12] Tsukamoto, Y., Sakaiuchi, T., Hiroi, S., Furuya, M., Tsuchiya, S., Sasaki, F., Miki, N. and Taira, E. (2003) Expression of Gicerin Enhances the Invasive and Metastatic Activities of a Mouse Mammary Carcinoma Cell Line. International Journal of On- 
cology, 23, 1671-1678. https://doi.org/10.3892/ijo.23.6.1671

[13] Tsukamoto, Y., Egawa, M., Hiroi, S., Furuya, M., Tsuchiya, S., Sasaki, F., Miki, N. and Taira, E. (2003) Gicerin, an Ig-Superfamily Cell Adhesion Molecule, Promotes the Invasive and Metastatic Activities of a Mouse Fibroblast Cell Line. Journal of Cellular Physiology, 197, 103-109. https://doi.org/10.1002/jcp.10348

[14] Tsukamoto, Y., Taira, E., Kotani, T., Yamate, J., Wada, S., Takaha, N., Miki, N. and Sakuma, S. (1996) Involvement of Gicerin, a Cell Adhesion Molecule, in Tracheal Development and Regeneration. Cell Growth \& Differentiation, 7, 1761-1767.

[15] Tsukamoto, Y., Matsumoto, T., Kotani, T., Taira, E., Takaha, N., Miki, N., Yamate, J. and Sakuma, S. (1997) The Expression of Gicerin, a Cell Adhesion Molecule, in Regenerating Process of Collecting Ducts and Ureters of the Chicken Kidney after the Nephrotrophic Strain of Infectious Bronchitis Virus Infection. Avian Pathology, 26, 245-255. https://doi.org/10.1080/03079459708419209

[16] Tsukamoto, Y., Taira, E., Yamate, J., Nakane, Y., Kajimura, K., Tsudzuki, M., Kiso, Y., Kotani, T., Miki, N. and Sakuma, S. (1997) Gicerin, a Cell Adhesion Molecule, Participates in the Histogenesis of Retina. Journal of Neurobiology, 33, 769-780. https://doi.org/10.1002/(SICI)1097-4695(19971120)33:6<769::AID-NEU5>3.0.CO;2-7

[17] Tsukamoto, Y., Matsumoto, T., Taira, E., Kotani, T., Yamate, J., Takaha, N., Tatesaki, R., Namikawa, T., Miki, N. and Sakuma, S. (1998) Adhesive Ability of Gicerin, a Cell Adhesion Molecule, in Kidneys and Nephroblastomas of Chickens. Cell and Tissue Research, 292, 137-142. https://doi.org/10.1007/s004410051043

[18] Tsukamoto, Y., Taira, E., Nakane, Y., Tsudzuki, M., Kohama, K., Amin, H., Miki, N. and Sasaki, F. (1999) Expression of Gicerin, a Cell Adhesion Molecule, in the Abnormal Retina in Silver Plumage Color Mutation of Japanese Quail (Coturnix japonica). Neuroscience Letters, 266, 53-56. https://doi.org/10.1016/S0304-3940(99)00256-6

[19] Tsukamoto, Y., Taira, E., Kajimura, K., Yamate, J., Kotani, T., Amin, H., Kohama, K., Sakuma, S., Miki, N. and Sasaki, F. (1999) Involvement of Gicerin, a Cell Adhesion Molecule, in Development and Regeneration of Oviduct, and Metastasis of Oviductal Adenocarcinomas of the Chicken. Experimental Cell Research, 247, 329-338. https://doi.org/10.1006/excr.1998.4367

[20] Taira, E., Takaha, N. and Miki, N. (1993) Extracellular Matrix Proteins with Neurite Promoting Activity and Their Receptors. Neuroscience Research, 17, 1-8. https://doi.org/10.1016/0168-0102(93)90023-J

[21] Hiroi, S., Tsukamoto, Y., Sasaki, F., Miki, N. and Taira, E. (554) Involvement of Gicerin, a Cell Adhesion Molecule, in Development and Regeneration of Chick Sciatic Nerve. FEBS Letters, 554, 311-314. https://doi.org/10.1016/S0014-5793(03)01176-1

[22] Adachi, K., Hattori, Kato, H., Inai, M., Tsukamoto, M., Handharyani, E., Taira, E. and Tsukamoto, Y. (2010) Involvement of Gicerin, a Cell Adhesion Molecule, in the Portal Metastasis of Rat Colorectal Adenocarcinoma Cells. Oncology Reports, 24, 1427-1431.

[23] Kirimura, N., Kubota, Y., Adachi, K. and Tsukamoto, Y. (2014) Involvement of Gicerin, a Cell Adhesion Molecule, in the Hematogenous Metastatic Activities of a Melanoma Cell Line. American International Journal of Biology, 2, 65-75. https://doi.org/10.15640/aijb.v2n3-4a4

[24] Kubota, Y., Kirimura, N., Shiba, H., Adachi, K. and Tsukamoto, Y. (2015) SC1, an Ig-Superfamily Cell Adhesion Molecule, Is Involved in the Brain Metastatic Activity of Lung Cancer Cells. Oncology Letters, 10, 2214-2218. https://doi.org/10.3892/ol.2015.3576

[25] Tsukamoto, Y., Kataoka, B., Adachi, K., Kato, H., Inai, M., Tsukamoto, M., Hand- 
hartani, E. and Taira, E. (2010) Involvement of Gicerin, a Cell Adhesion Molecule, in a Dermal Autograft Chicken Model. International Journal of Molecular Medicine, 26, 661-666. https://doi.org/10.3892/ijmm_00000511

[26] Takeichi, M. (1993) Cadherins in Cancer; Implications for Invasion and Metastasis. Current Opinion in Cell Biology, 5, 806-811.

https://doi.org/10.1016/0955-0674(93)90029-P

[27] Takaha, N., Taira, E., Taniura, H., Nagino, T., Tsukamoto, Y., Matsumoto, T., Kotani, T., Sakuma, S. and Miki, N. (1995) Expression of Gicerin in Development, Oncogenesis and Regeneration of Chick Kidney. Differentiation, 58, 313-320. https://doi.org/10.1046/j.1432-0436.1995.5850313.x

[28] Okumura, S., Muraoka, O., Tanaka, H., Tsukamoto, Y., Kohama, K., Miki, N. and Taira, E. (2001) Involvement of Gicerin in the Extension of Microvilli. Experimental Cell Research, 271, 269-276. https://doi.org/10.1006/excr.2001.5393

[29] Albelda, S.M. (1993) Role of Integrins and Other Cell Adhesion Molecules in Tumor Progression and Metastasis. Laboratory Investigation, 68, 4-17.

[30] Cunningham, B.A. (1995) Cell Adhesion Molecules as Morphoregulators. Current Opinion in Cell Biology, 7, 628-633. https://doi.org/10.1016/0955-0674(95)80103-0

[31] Tiwary, S., Preziosi, M., Rothberg, P.G., Zeitouni, N., Corson, N. and Xu, L. (2014) ERBB3 Is Required for Metastasis Formation of Melanoma Cells. Oncogenesis, 3, e110. https://doi.org/10.1038/oncsis.2014.23 